\title{
Prevalence and risk factors of trematode infection in swamp buffaloes reared under different agro-climatic conditions in Java Island of Indonesia
}

\author{
Nanis Nurhidayah ${ }^{1}$, Fadjar Satrija ${ }^{1,2}$, Elok Budi Retnani ${ }^{1,2}$, Dewi Apri Astuti ${ }^{3}$ and Sri Murtini ${ }^{1,2}$
}

\begin{abstract}
1. Parasitology and Medical Entomology Study Program, Graduate School of IPB University, Bogor, Indonesia; 2. Department of Animal Infectious Diseases and Veterinary Public Health, Faculty of Veterinary Medicine, IPB University, Bogor, Indonesia; 3. Department of Animal Nutrition and Feed Technology, Faculty of Animal Science, IPB University, Bogor, Indonesia.

Corresponding author: Fadjar Satrija, e-mail: fadjar_s@apps.ipb.ac.id

Co-authors: NN: nanis_doctor@apps.ipb.ac.id, EBR: elokbeer14@gmail.com, DAA: dewiapriastuti86@gmail.com, SM: smurtinifs@yahoo.com
\end{abstract}

Received: 20-11-2019, Accepted: 02-03-2020, Published online: 15-04-2020

doi: www.doi.org/10.14202/vetworld.2020.687-694 How to cite this article: Nurhidayah N, Satrija F, Retnani EB, Astuti DA, Murtini S (2020) Prevalence and risk factors of trematode infection in swamp buffaloes reared under different agroclimatic conditions in Java Island of Indonesia, Veterinary World, 13(4): 687-694.

\begin{abstract}
Background and Aim: This study was conducted to estimate the prevalence and intensity and to identify the associated risk factors and impact of trematode infection in swamp buffaloes reared under different agro-climatic conditions in Java, Indonesia.

Materials and Methods: A total of 580 fecal samples were collected from swamp buffaloes in five different agro-climatic areas in Banten and Central Java Provinces, Indonesia. The fecal samples were examined using the Danish Bilharziasis Laboratory Technique to determine the prevalence and intensity of trematode infection. The risk factors for infection were determined from an in-depth interview of owners/keepers, and the results were analyzed using Chi-square tests and multiple logistic regression. The infection was also correlated with swamp buffalo production parameters (body weight and body condition score $[\mathrm{BCS}])$.

Results: From all fecal samples, the overall prevalence of trematode infection was $64.83 \%$, which comprised Fasciola spp. (16.03\%; mean eggs per gram [EPG] \pm SD: $1.02 \pm 0.43)$ and Paramphistomatidae (62.93\%; mean EPG \pm SD: $1.01 \pm 0.66)$. The main risk factor for trematode infection was feeding animals with rice straw (odds ratio [OR]: 40.124); the risk of trematode infection was 40.142 times higher in buffaloes that consumed rice straw. Other risk factors included the frequency of anthelmintic treatment (OR: 4.666), age (OR: 0.449), and drinking water source (OR: 0.358). Trematode infection did not significantly affect the body weight or BCS of swamp buffaloes.
\end{abstract}

Conclusion: Although the prevalence of trematode infection was high in swamp buffaloes, the intensity of infection was low, and the infection did not affect the animals' physical parameters.

Keywords: epidemiology, Indonesia, swamp buffalo, trematodes.

\section{Introduction}

Swamp buffalo (Bubalus bubalis) play an important role in the agricultural economy in most developing Asian countries by providing meat, farm animal labor, and a source of organic fertilizer [1]. In Indonesia, the animals are also part of social culture, for example, in family savings and as sacrificial animals in traditional and/or religious ceremonies [2]. In 2018, the swamp buffalo population in Indonesia was 1,932,927 heads; these animals were geographically distributed in Sumatera, Java, Kalimantan, and Sulawesi, as well as in West and East Nusa Tenggara [3]. Swamp buffaloes in seven regions of Indonesia (Aceh, Riau, Madiun,

Copyright: Nurhidayah, et al. Open Access. This article is distributed under the terms of the Creative Commons Attribution 4.0 International License (http://creativecommons.org/licenses/ by/4.0/), which permits unrestricted use, distribution, and reproduction in any medium, provided you give appropriate credit to the original author(s) and the source, provide a link to the Creative Commons license, and indicate if changes were made. The Creative Commons Public Domain Dedication waiver (http:// creativecommons.org/publicdomain/zero/1.0/) applies to the data made available in this article, unless otherwise stated.
Blitar, Lombok, South Kalimantan, and Tana Toraja) share similarities in genetics and their management systems. The majority of these livestock are reared under traditional husbandry systems characterized by a lack of knowledge and technology [4]. The previous studies have reported trematode infection in buffaloes worldwide [5-7]. Although infected animals may not exhibit any clinical signs, infection reduces livestock performance, for example, by slowing growth rate, lowering body weight, and reducing milk production $[8,9]$. In the acute form of trematode infection, extensive organ damage and even sudden death can occur due to the migration of high numbers of immature flukes [10].

Studies on trematode infection in Indonesian buffalo have been very limited, although a high prevalence was reported in South Kalimantan, Aceh, and Central Sulawesi [11-13]. The disease situation potentially differs across the country since Indonesia is divided into 14 agro-climatic regions, according to the number of annual wet and dry months accumulated over 10 years of observation [14]. 
Here, we conducted a study of swamp buffalo in several districts and provinces in Java Island of Indonesia with the following aims: (1) To estimate the prevalence of trematode infection, (2) to identify risk factors for trematode infection, and (3) to determine the impact of trematode infection on the production performance of livestock. This study is important because we are accumulating the fundamental data required for future control of trematode infection in Indonesian swamp buffaloes within and outside of the study location.

\section{Materials and Methods}

\section{Ethical approval}

The procedures applied throughout this study have been approved by the Animal Care and Use Committee of IPB University No. 65-2017 IPB and 133-2018 IPB.

\section{Study area}

A cross-sectional study was carried out from March 2017 to May 2018 in 12 sub-districts of
Indonesia, including eight in the Districts of Serang and Lebak, Banten Province, and four in Brebes District, Central Java Province. The study areas were categorized into five different agro-climatic types based on recent data of the Oldeman climate map from the nearest climate stations (Table-1 and Figure-1).

\section{Sample and data collection procedures}

Fecal samples were randomly collected from 580 swamp buffaloes, including groups of pre-weaned calves (0-8 months), calves ( $>8-18$ months), young animals ( $>18-32$ months), and adults ( $>32$ months). A minimum fecal sample of $15 \mathrm{~g}$ was collected from each animal. The samples were placed in labeled plastic containers, stored in a cooler box, and transported to the Laboratory of Helminthology, Department of Animal Infectious Diseases and Veterinary Public Health, Faculty of Veterinary Medicine, IPB University.

Subsequently, the production parameters of the fecal-sampled animals, including their body condition score (BCS) and girth, were evaluated [15]. BCS was

Table-1: Agro-climatic types of the study sites based on the Oldeman classification map.

\begin{tabular}{|c|c|c|c|}
\hline \multirow[t]{2}{*}{ Agro-climatic region type } & \multicolumn{2}{|c|}{ Number of consecutive } & \multirow[t]{2}{*}{ Location } \\
\hline & Wet months & Dry months & \\
\hline $\mathrm{B} 2$ & $7-9$ & $2-4$ & $\begin{array}{l}\text { Panggarangan, Lebak District, Banten } \\
\text { Bantarkawung, Brebes District, Central Java }\end{array}$ \\
\hline $\mathrm{C} 1$ & $5-6$ & $<2$ & $\begin{array}{l}\text { Cipanas, Lebak District, Banten } \\
\text { Cinangka, Serang District, Banten }\end{array}$ \\
\hline $\mathrm{C} 2$ & $5-6$ & $2-4$ & $\begin{array}{l}\text { Cinangka, Serang District, Banten } \\
\text { Mancak, Serang District, Banten } \\
\text { Salem, Brebes District, Central Java } \\
\text { Tonjong, Brebes District, Central Java }\end{array}$ \\
\hline $\mathrm{C} 3$ & $5-6$ & $5-6$ & $\begin{array}{l}\text { Anyer, Serang District, Banten } \\
\text { Cikulur, Lebak District, Banten } \\
\text { Cileles, Lebak District, Banten } \\
\text { Cinangka, Serang District, Banten }\end{array}$ \\
\hline D4 & $3-4$ & $>6$ & Brebes, Brebes District, Central Java \\
\hline
\end{tabular}

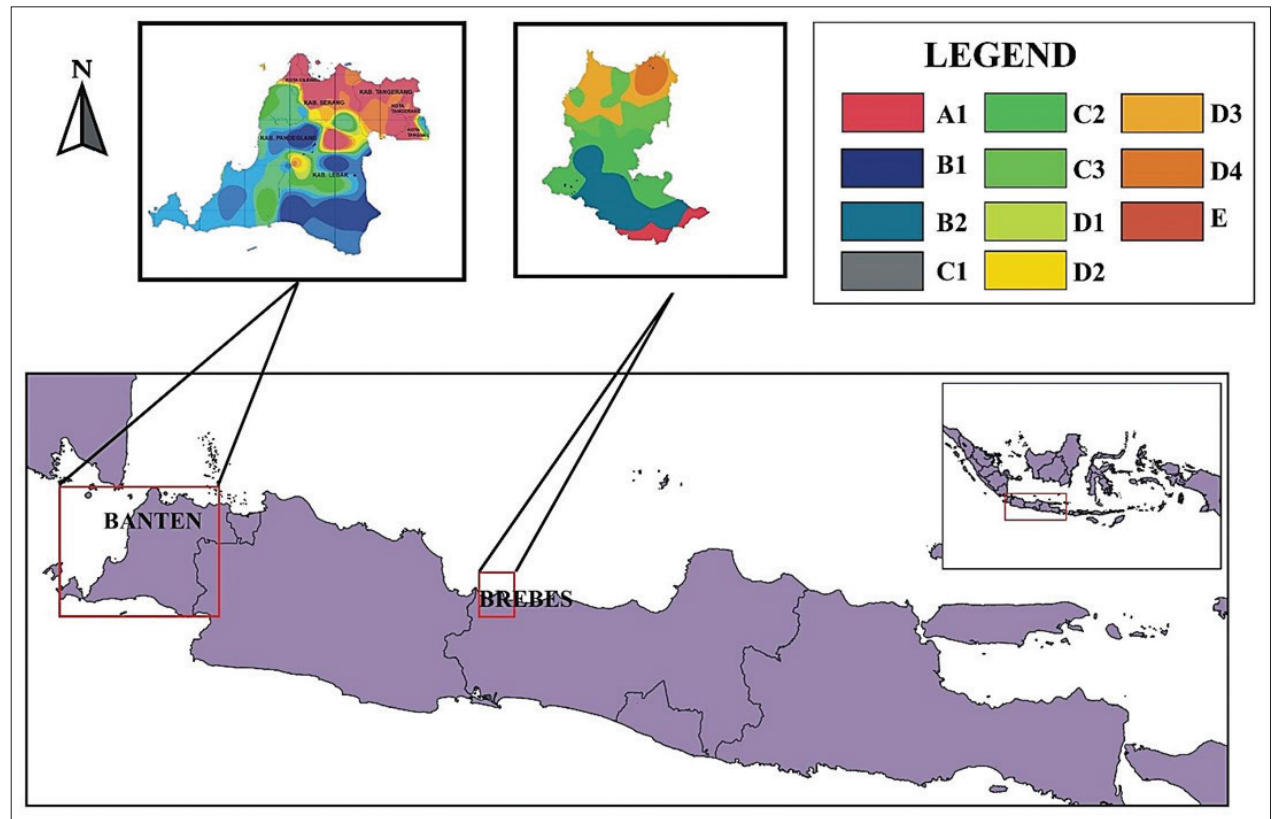

Figure-1: Agro-climatic map of study locations (the map was re-drawn by Nanis Nurhidayah using Oldeman classification Maps from Pondok Betung Climatology Station and Semarang Climatology Station). 
estimated by measuring eight skeletal checkpoints. Measurements of girth can be used to estimate body weight by ANIMETER ${ }^{\circledR}$; girth data were transformed into kilograms [16].

An in-depth interview conducted through a structured questionnaire was targeted at 317 owners/ keepers to assess the potential risk factors of trematode infection. The interview included questions on animal and owner status, management systems, and animal health management.

\section{Coprological technique}

Fecal samples were examined using the Danish Bilharziasis Laboratory (DBL) technique [17] with slight modifications. Specifically, 5-g samples were weighed, added to $10 \mathrm{ml}$ of water, homogenized, and filtered using $400-\mu \mathrm{m}, 100-\mu \mathrm{m}$, and $45-\mu \mathrm{m}$ sieves. The fecal material that remained on the $45-\mu \mathrm{m}$ sieve was collected into a sedimentation tube, which was refilled with water. The sample was then centrifuged $2000 \mathrm{rpm}$ for 10 minutes, and water was added to make a volume of $2.25 \mathrm{ml}$. From this mixture, a $150-\mu 1$ aliquot of each sample was added to a counting slide. The number of trematode eggs per gram (EPG) in fecal samples was obtained from three counting slides. The animal was considered to be positively infected by trematodes, if trematode eggs were observed during the microscopic examination. The prevalence of infection was calculated for total samples, each parasite, and each category (i.e., age group, sub-district, sex, and type of agro-climate). The infection intensity was determined based on EPG and the geometric mean.

\section{Statistical analysis}

The prevalence and intensity of infection were represented by descriptive statistics, with $95 \%$ exact confidence intervals (CIs). Risk factors were analyzed using Chi-square tests and multiple logistic regressions. A Kendall's tau-b correlation was run to determine the relationships between infection intensity and production parameters. All statistical procedures were processed in SPSS v.16 (IBM Corp., NY, USA) for Windows.

\section{Results}

\section{Prevalence and infection intensity}

The results of the coprological examination showed that 376 of 580 , i.e., $64.83 \%$ (CI: 60.94$68.71 \%$ ), swamp buffaloes had excreted trematode eggs. Two trematode egg types were identified microscopically: Fasciola spp. in 16.03\% (CI: 13.05$19.02 \%$ ) of samples and Paramphistomatidae in 62.93\% (CI: $59.00-66.86 \%$ ). The infection intensity of Fasciola spp. and Paramphistomatidae was 0.74 EPG (CI: 0.19-1.29 EPG) and 3.60 EPG (CI: 2.075.13 EPG), respectively (Figure-2).

The prevalence and infection intensity of Fasciola spp. according to several variables is shown in Table-2. The prevalence and infection intensity of Fasciola spp. was higher in female buffaloes

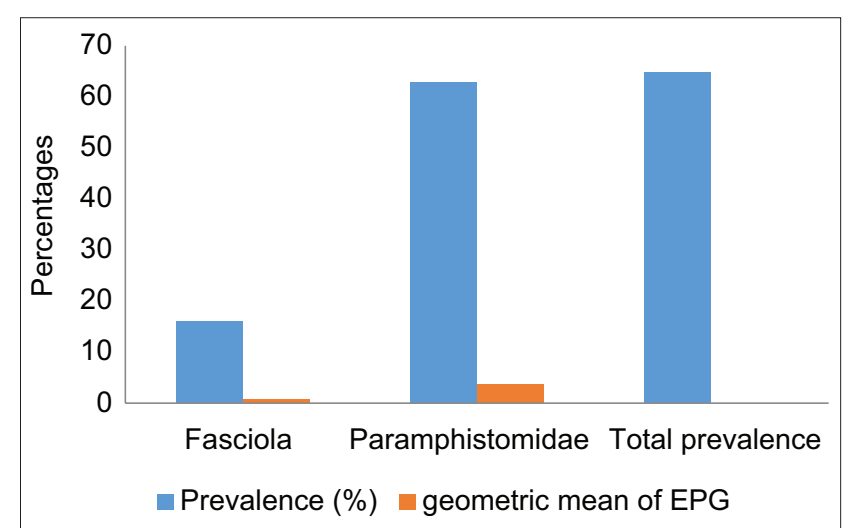

Figure-2: Prevalence and intensity of trematode infection in Indonesian swamp buffaloes.

(17.26\%, CI: 13.86-20.66\%; 0.79 EPG, CI: 0.71-1.41 EPG) than in males $(10.48 \%$, CI: $4.62-16.33 \%$; 0.46 EPG, CI: 0.26-0.65 EPG). According to age group, the highest trematode prevalence and infection intensity occurred in adult buffaloes, followed by calves, pre-weaned calves, and young animals, respectively. Of 110 swamp buffaloes had a BCS of 2.5, 32 were infected by Fasciola spp. with an infection intensity of 0.56 EPG (CI: 0-1.19 EPG).

We made interesting observations related to trematode infection in various sub-districts and agro-climatic areas. Although the highest prevalence of Fasciola spp. was observed in the Cinangka sub-district, the swamp buffaloes in Tonjong excreted more eggs than those in any other area. Similarly, the swamp buffaloes in agro-climatic area $\mathrm{C} 1$ had a slightly higher prevalence of infection (20\%, CI: 6.75 $33.25 \%$ ) than buffaloes in other areas, but the highest infection intensity of Fasciola spp. was found in the agro-climatic area $\mathrm{D} 4$.

As shown in Table-3, the prevalence and infection intensity of Paramphistomatidae was higher compared with those of Fasciola spp. across all variables; however, there was a similarity in the infection pattern. Paramphistomatidae was more prevalent in females, adults, and buffaloes with a BCS of 2.5. In the district of Anyer, all swamp buffaloes tested was infected by Paramphistomatidae (100\%); whereas buffaloes in Tonjong excreted a higher rate of eggs in their feces (18.51 EPG, CI: 12.34-24.67 EPG). When analyzing infection according to the agro-climatology of study areas, Paramphistomatidae prevalence was high in all areas $(>60 \%)$, but the highest intensity was recorded in the agro-climatic area $\mathrm{C} 2$.

\section{Risk factors for trematode infection}

Results of Chi-square analysis indicated that sex, age, availability of wallow, straw feeding, drinking water source, and frequency of anthelmintic treatment were all significantly related to infection $(\mathrm{p}<0.05)$. In contrast, variation in agro-climate did not significantly impact trematode infection (Table-4). The odds ratio (OR) of animals that were fed with rice straw was 40.124 , which meant that these animals were 40.124 times more likely 
Table-2: Prevalence and intensity of Fasciola spp. infection in Indonesian swamp buffaloes.

\begin{tabular}{|c|c|c|c|c|}
\hline Variables & Sample size (\%) & $\begin{array}{c}\text { Number of positive } \\
\text { samples }\end{array}$ & $\begin{array}{c}\text { Prevalence } \\
\text { (95\% exact } \mathrm{CI})\end{array}$ & $\begin{array}{c}\text { Geometric mean EPG } \\
(95 \% \text { exact } \mathrm{CI})\end{array}$ \\
\hline \multicolumn{5}{|l|}{ Sub-districts } \\
\hline Anyer & $12(2.07)$ & 2 & $16.67(0-37.75)$ & $0.43(0-0.92)$ \\
\hline Cinangka & $105(18.10)$ & 28 & $26.67(18.21-35.13)$ & $0.54(0.09-1.00)$ \\
\hline Mancak & $22(3.79)$ & 2 & $9.09(0-21.10)$ & $0.25(0)$ \\
\hline Padarincang & $11(1.9)$ & 1 & $9.09(0-26.08)$ & $0.50(0)$ \\
\hline Cipanas & $47(8.1)$ & 10 & $21.28(9.58-32.98)$ & $0.45(0-0.93)$ \\
\hline Cikulur & $37(6.38)$ & 3 & $8.11(0-16.90)$ & $0.66(0-1.89)$ \\
\hline Cileles & $19(3.28)$ & 5 & $26.32(6.52-46.12)$ & $0.59(0.17-1.01)$ \\
\hline Panggarangan & $87(15)$ & 16 & $18.39(10.25-26.53)$ & $0.65(0-1.69)$ \\
\hline Salem & $51(8.79)$ & 5 & $9.80(1.64-17.97)$ & $1.32(0.34-2.30)$ \\
\hline Bantarkawung & $90(15.52)$ & 9 & $10.00(3.80-16.20)$ & $1.36(0.70-2.02)$ \\
\hline Tonjong & $69(11.9)$ & 9 & $13.04(5.10-20.99)$ & $2.32(0-7.01)$ \\
\hline Brebes & $30(5.17)$ & 3 & $10.00(0-20.74)$ & $1(0)$ \\
\hline \multicolumn{5}{|l|}{ Sex } \\
\hline Male & $105(18.1)$ & 11 & $10.48(4.62-16.33)$ & $0.46(0.26-0.65)$ \\
\hline Female & $475(81.9)$ & 82 & $17.26(13.86-20.66)$ & $0.79(0.71-1.41)$ \\
\hline \multicolumn{5}{|l|}{ Age } \\
\hline $0-8$ months & $56(9.66)$ & 7 & $12.50(3.84-21.16)$ & $0.43(0.31-0.56)$ \\
\hline$>8-18$ months & $56(9.66)$ & 8 & $14.29(5.12-23.45)$ & $0.45(0-2.09)$ \\
\hline$>18-32$ months & $81(13.97)$ & 6 & $7.41(1.70-13.11)$ & $0.57(0.21-0.93)$ \\
\hline >32 months & $387(66.72)$ & 72 & $18.60(14.73-22.48)$ & $0.80(0.46-1.15)$ \\
\hline \multicolumn{5}{|l|}{$\mathrm{BCS}$} \\
\hline 2 & $5(0.86)$ & 0 & 0 & 0 \\
\hline 2.5 & $110(18.97)$ & 32 & $29.09(20.60-37.58)$ & $0.56(0-1.19)$ \\
\hline 3 & $295(50.86)$ & 44 & $14.92(10.85-18.98)$ & $0.71(0-1.72)$ \\
\hline 3.5 & $148(25.52)$ & 15 & $10.14(5.27-15.00)$ & $1.38(0.34-2.42)$ \\
\hline 4 & $22(3.79)$ & 2 & $9.09(0-21.10)$ & $0.78(0.43-2.57)$ \\
\hline \multicolumn{5}{|l|}{ Agro-climatic area } \\
\hline B2 & $237(40.86)$ & 32 & $13.50(9.15-17.85)$ & $0.78(0.22-1.35)$ \\
\hline $\mathrm{C} 1$ & $35(6.03)$ & 7 & $20.00(6.75-33.25)$ & $0.41(0-1.10)$ \\
\hline $\mathrm{C} 2$ & $185(31.9)$ & 36 & $19.46(13.75-25.16)$ & $0.89(0-2.19)$ \\
\hline C3 & $93(16.03)$ & 15 & $16.13(8.65-23.60)$ & $0.53(0.10-0.95)$ \\
\hline D4 & $30(5.17)$ & 3 & $10.00(0-20.74)$ & $1(0)$ \\
\hline
\end{tabular}

EPG=Eggs per gram, $\mathrm{CI}=$ Confidence interval

to be infected with trematodes. In addition, trematode infection increased 4.666-fold in animals that received no anthelmintic treatment (OR: 4.666). An age-dependent pattern was also observed for OR values (Table-5): Adult swamp buffaloes were most likely to be infected (OR: 0.449$)$, followed by young animals (OR: 0.350 ), calves (OR: 0.084), and pre-weaned calves (used as a reference).

\section{Trematode infection impact correlated with produc- tion parameters}

The results of Kendall's tau-b correlation analysis for variables are shown in Table- 6 . A low-positive correlation was observed between the two production parameters, BCS and body weight $(\mathrm{p}<0.05)$. However, there was no significant correlation between the intensity of trematode infection and the production performance parameters. The EPG of Fasciola spp. was not significantly correlated with either BCS or body weight; in contrast, both body weight and BCS were positively correlated with Paramphistomatidae EPG (Kendall's tau-b correlation coefficient: 0.237 and 0.254 , respectively, $(\mathrm{p}<0.001)$.

\section{Discussion}

The high level of trematode infection we observed in Indonesian swamp buffaloes is in agreement with reports from other areas of the country $[12,13]$. The prevalence of fasciolosis in Indonesian swamp buffaloes tends to be higher than in the riverine types from India and Pakistan $[18,19]$. The wet tropical environment consists of the perfect temperature and humidity for infection, which is likely the primary determining factor for this variation in prevalence among countries. In this study, we used the DBL technique to collect data; the method is simple, it does not require special reagents or equipment, nor does it require toxins, and it enables clear observation of trematode eggs. The most practical limitations of this technique were the number of feces samples required and the time required for preparation and analysis. Nevertheless, the DBL technique is essential for both the detection and quantification of trematode eggs in buffaloes, dogs, cattle, and pigs in the Philippines and Indonesia [20,21]. Using this technique, we found two different egg types belonging to Fasciola spp. and Paramphistomatidae, a finding that is in accord with studies of buffalo and beef cattle in Central Sulawesi and Bojonegoro, East Java [21,22].

Swamp buffaloes play an important role as the main definitive host of Fasciola gigantica in Indonesia. Mukhlis [23] suggested that F. gigantica is 
Table-3: Prevalence and intensity of paramphistomatida in Indonesian swamp buffaloes.

\begin{tabular}{|c|c|c|c|c|}
\hline Variables & $\begin{array}{c}\text { Sample size } \\
(\%)\end{array}$ & $\begin{array}{c}\text { Number of } \\
\text { positive samples }\end{array}$ & $\begin{array}{c}\text { Prevalence }(95 \% \\
\text { exact } \mathrm{CI})\end{array}$ & $\begin{array}{c}\text { Geometric mean } \\
\text { EPG }(95 \% \text { exact CI })\end{array}$ \\
\hline \multicolumn{5}{|l|}{ Sub-districts } \\
\hline Anyer & $12(2.07)$ & 12 & $100(100-100)$ & $2.48(0-5.20)$ \\
\hline Cinangka & $105(18.10)$ & 68 & $64.76(55.26-73.90)$ & $1.88(0-4.19)$ \\
\hline Mancak & $22(3.79)$ & 7 & $31.82(12.36-51.28)$ & $0.67(0.31-1.03)$ \\
\hline Padarincang & $11(1.9)$ & 2 & $18.18(0-40.97)$ & $1(0)$ \\
\hline Cipanas & $47(8.1)$ & 35 & $74.47(62.00-86.93)$ & $2.87(1.35-4.38)$ \\
\hline Cikulur & $37(6.38)$ & 27 & $72.97(58.66-87.28)$ & $1.41(0-4.09)$ \\
\hline Cileles & $19(3.28)$ & 17 & $89.47(75.67-100)$ & $2.60(0.08-5.12)$ \\
\hline Panggarangan & $87(15)$ & 76 & $87.36(80.37-94.34)$ & $3.99(1.27-6.70)$ \\
\hline Salem & $51(8.79)$ & 15 & $29.41(16.91-41.92)$ & $3.14(0-7.87)$ \\
\hline Bantarkawung & $90(15.52)$ & 30 & $33.33(23.59-43.07)$ & $3.15(0-6.71)$ \\
\hline Tonjong & $69(11.9)$ & 54 & $78.26(68.53-87.99)$ & $18.51(12.34-24.67)$ \\
\hline Brebes & $30(5.17)$ & 22 & $73.33(57.51-89.16)$ & $6.19(0-12.73)$ \\
\hline \multicolumn{5}{|c|}{ (20) } \\
\hline Male & $105(18.1)$ & 49 & $46.67(37.12-56.21)$ & $2.41(0-7.04)$ \\
\hline Female & $475(81.9)$ & 316 & $66.53(62.28-70.77)$ & $3.83(2.21-5.45)$ \\
\hline \multicolumn{5}{|l|}{ Age } \\
\hline $0-8$ months & $56(9.66)$ & 22 & $39.29(26.49-52.08)$ & $0.96(0-2.18)$ \\
\hline$>8-18$ months & $56(9.66)$ & 28 & $50.00(26.90-63.10)$ & $2.05(0-7.57)$ \\
\hline$>18-32$ months & $81(13.97)$ & 38 & $46.91(36.05-57.78)$ & $3.50(0-7.93)$ \\
\hline$>32$ months & $387(66.72)$ & 277 & $71.58(67.08-76.07)$ & $4.20(2.74-5.94)$ \\
\hline \multicolumn{5}{|l|}{ BCS } \\
\hline 2 & $5(0.86)$ & 4 & $80.00(44.94-100)$ & $0.79(0-1.88)$ \\
\hline 2.5 & $110(18.97)$ & 88 & $80.00(72.52-87.48)$ & $3.19(1.38-5.00)$ \\
\hline 3 & $295(50.86)$ & 180 & $61.02(55.45-66.58)$ & $2.83(0.99-4.67)$ \\
\hline 3.5 & $148(25.52)$ & 78 & $52.70(44.66-60.75)$ & $8.11(3.28-12.95)$ \\
\hline 4 & $22(3.79)$ & 15 & $68.18(48.72-87.64)$ & $2.93(0-9.50)$ \\
\hline \multicolumn{5}{|l|}{ Agro-climatic areas } \\
\hline B2 & $237(40.86)$ & 146 & $61.60(55.41-67.80)$ & $3.25(1.54-4.95)$ \\
\hline $\mathrm{C} 1$ & $35(6.03)$ & 24 & $68.57(53.19-83.95)$ & $1.77(0-3.69)$ \\
\hline $\mathrm{C} 2$ & 185 (31.9) & 112 & $60.54(53.50-67.58)$ & $6.01(2.22-6.01)$ \\
\hline $\mathrm{C} 3$ & $93(16.03)$ & 61 & $65.69(55.94-75.25)$ & $1.96(0-4.47)$ \\
\hline D4 & $30(5.17)$ & 22 & 73.33(57.51-89.16) & $6.19(0-12.73)$ \\
\hline
\end{tabular}

$\mathrm{BCS}=$ Body condition score, $\mathrm{EPG}=$ Eggs per gram, $\mathrm{CI}=$ Confidence interval

Table-4: Chi-square analysis of trematode infection in Indonesian swamp buffaloes.

\begin{tabular}{|c|c|c|c|}
\hline Variables & Number of non-infected buffalo & Number of infected buffalo & p-value \\
\hline Sex & & & $0.000^{\mathrm{a}}$ \\
\hline Male & 32 & 29 & \\
\hline Female & 71 & 185 & \\
\hline Age & & & $0.001^{\mathrm{a}}$ \\
\hline Pre-weaned calves & 17 & 12 & \\
\hline Calves & 14 & 16 & \\
\hline Young & 18 & 28 & \\
\hline Adult & 54 & 158 & \\
\hline Wallow & & & $0.032^{\mathrm{a}}$ \\
\hline No & 73 & 125 & \\
\hline Yes, available & 30 & 89 & \\
\hline Rice-straw feeding & & & $0.011^{\mathrm{a}}$ \\
\hline & 2 & 21 & \\
\hline Yes & 101 & 193 & \\
\hline Drinking water-source & & & $0.003^{a}$ \\
\hline Tap water & 1 & 6 & \\
\hline Pond & 99 & 176 & \\
\hline Mix & 3 & 32 & \\
\hline Frequency of anthelmintic treatment & & & $0.014^{\mathrm{a}}$ \\
\hline Monthly & 48 & 71 & \\
\hline Sick only & 29 & 96 & \\
\hline None & 26 & 47 & \\
\hline
\end{tabular}

a Statistical significance $(p<0.05)$

the only endemic Fasciola species that infects ruminants in Indonesia; his hypothesis is based on the limited availability of the specific intermediate host snail in Indonesia, namely, Lymnaea rubiginosa. According to molecular characterization and phylogenic analysis, F. gigantica was the only species found in West Java, 
Table-5: Multivariate analysis of risk factors for trematode infection in Indonesian swamp buffaloes.

\begin{tabular}{|c|c|c|c|}
\hline Variables & Odds ratio & $95 \% \mathrm{CI}$ & p-value \\
\hline \multicolumn{4}{|l|}{ Rice-straw feeding } \\
\hline No & & Reference & \\
\hline Yes & 40.124 & $2.438-660.413$ & 0.010 \\
\hline Frequency of anthelmintic treatment & & & 0.000 \\
\hline Monthly & & Reference & \\
\hline Sick only & 0.773 & $0.256-2.329$ & 0.647 \\
\hline None & 4.666 & $1.686-12.912$ & 0.003 \\
\hline Age group & & & 0.000 \\
\hline Pre-weaning calves & & Reference & \\
\hline Calves & 0.084 & $0.028-0.257$ & 0.000 \\
\hline Young animals & 0.350 & $0.124-0.991$ & 0.048 \\
\hline Adults & 0.449 & $0.200-1.008$ & 0.052 \\
\hline Drinking water source & & & 0.004 \\
\hline Tap water & & Reference & \\
\hline Pond & 0.358 & $0.011-12.174$ & 0.568 \\
\hline Mix source & 0.028 & $0.003-0.246$ & 0.001 \\
\hline Constant & 7.528 & & 0.086 \\
\hline
\end{tabular}

$\mathrm{CI}=$ Confidence interval

Table-6: Correlation coefficients for trematode infection correlated with production performance parameters in Indonesian swamp buffaloes.

\begin{tabular}{lcccc}
\hline & BCS & BW & EPG Fasciola spp. & EPG Paramphistomatidae \\
\hline BCS & 1.000 & $0.125^{\mathrm{a}}$ & -0.022 & $0.237^{\mathrm{b}}$ \\
BW & & 1.000 & 0.069 & $0.254^{\mathrm{b}}$ \\
EPG Fasciola spp. & & 1.000 & $0.196^{\mathrm{b}}$ \\
EPG Paramphistomatidae & & & & 1.000 \\
\hline
\end{tabular}

aStatistically significant $(p<0.05)$, bStatistically significant $(p<0.01), B C S=$ Body condition score, BW=Bodyweight, $\mathrm{EPG}=$ Eggs per gram

which is closed to Fasciola found in other Asian countries. As yet, no hybrid Fasciola has been detected in Indonesia unlike in most other Asia countries [24].

In this study, the identification of parasites was based on the morphology of their eggs on microscopic examination. The distinctive characteristic of $F$. gigantica eggs compared with eggs from other members of Fasciola (e.g., Fasciola hepatica) is their size: F. gigantica eggs are larger $(90-100 \mu \mathrm{m} \times 170$ $190 \mu \mathrm{m})$ than $F$. hepatica eggs $(63-79 \mu \mathrm{m} \times 126$ $133 \mu \mathrm{m}$ ) [23]. Liver fluke (i.e., Fasciola) eggs are yellowish-brown, whereas the eggs of rumen flukes are much lighter in color. The size of Paramphistomatidae eggs is around 75-100 $\mu \mathrm{m} \times 115-175 \mu \mathrm{m}$ and buffaloes can be infected by the following species from the Paramphistomatidae family: Paramphistomum cervi and Cotylophoron cotylophorum [25]. Unfortunately, the microscopic examination technique used in this study was not precise enough to allow identification at the species level.

Of the trematode infections observed in this study, those from Paramphistomatidae were most prevalent and intense. This is likely related to the numerous species of Paramphistomatidae that infect Asian cattle and buffalo, as well as the variety and prevalence of its intermediate host, i.e., freshwater snail species from the families Planorbidae and Lymnaeidae [26]. The dominance of Paramphistomatidae over Fasciola spp. may also be explained by the location in which their cercariae encyst. The cercariae of $F$. hepatica encyst on the water surface and are, therefore, lost during heavy rain and/or flooding, whereas Paramphistomum daubneyi encyst at the bottom of water bodies near to the soil and develop to be the infective stage, i.e. metacercariae. Furthermore, soil provides the perfect level of moisture to maintain the development of $P$. daubneyi metacercariae [27].

Although the prevalence of both parasites was high in the present study, the infection intensity was relatively low. The observed EPG of Paramphistomatidae could be associated with the actual number of adult parasites in the abdominal region; however, thousands of adult rumen flukes may not induce clinical signs in their host [28]. In contrast, the low EPG of Fasciola spp. is likely caused by the trapping of eggs before they enter the intestinal lumen or by an over dispersion factor [29]. Evidence of an overdispersion also found in the previous case of fasciolosis in the cattle, so that highly infected animals excreted a very low number of eggs in their fecal sample [30]. Unfortunately, the low-infected animals could play an important role as an infection source for animals at the herd level since all of the respondents of this study said that they placed their buffaloes in communal cages and shared grazing areas.

Chi-square analysis revealed that there was no correlation between agro-climatic variation and parasitic infection in buffalo. This finding was similar to that of an epidemiological study of parasitic gastrointestinal infection on sheep, which took place over a year in various climatic areas in West Java, 
Indonesia [31]. A lack of correlation might have been the result of similarities between the five agro-climatic areas studied here, which are all categorized within the "wet climate region" group. The main risk factor for trematode infection in the present study was feeding animals with rice straw, which increased the risk of infection up to 40.124 times. This is unsurprising since most of the metacercariae of $F$. gigantica are reported to attach to the lower part of the rice stalk close to the soil $(0-10 \mathrm{~cm})$ and to inundate these plants [32]. Cattle and buffalo potentially became infected as rice fields were plowed or during grazing around the harvesting period. At the same time, buffaloes drink from and wallow in water sources; buffaloes that used ponds as a water source were 0.358 times more likely to become infected than those that used other water sources.

The age of swamp buffaloes was also a decisive factor in their infection status. Adults were at most risk of infection, and the likelihood of infection decreased with age. This result supports previous findings in cattle and buffalo from Pakistan [33]. The long prepatent period of the parasites and the high exposure of adult buffaloes to the pre-parasitic stages when the animals are used to plow paddy fields are thought to be the main causes of the increased risk in this age group [34]. Since the farmers kept adults for breeding purposes, more than $80 \%$ of the swamp buffalo population consisted of adults. This infection situation was aggravated further by a lack of anthelmintic therapy, which was shown to increase trematode infection 4.666-fold.

Correlation analysis revealed that the production performance of swamp buffaloes in the study areas was not affected by trematode infection. In contrast to our findings, Fasciola spp. induced negative effects on the body condition of riverine-type buffaloes in Egypt [35]. On the other hand, an experimental study of Indonesian buffalo infected by $F$. gigantica reported similar results to those in our study [36]. A group of Fasciola-infected buffalo calves exhibited similar daily weight gains to those of control animals, whereas Fasciola-infected Bali and Ongole calves added less daily weight than animals in a control group. An improved immune response, including the number of eosinophilia, Th2-related cytokines, and/or effective digestion and fermentation in the front abdomen, is known to play an important role in the initial response to these parasites $[37,38]$. On the other hand, the traditional semi-intensive system allows buffaloes to select their preferred feed, which potentially has anthelmintic properties (e.g., condensed tannins, alkaloids, glycosides, allicin, and santonin) [39]. Therefore, further analysis of the identity and content of forage consumed by buffaloes during the grazing period is required in the study location.

\section{Conclusion}

The parasitization of swamp buffaloes by Fasciola spp. and Paramphistomatidae is highly prevalent in different agro-climatic areas of Java Island, Indonesia, although the infection intensity in these areas is relatively low. Major risk factors for infection are feeding animals with rice straw, the frequency of anthelmintic treatment, animal age, and drinking water source. The infection did not produce a significant negative impact on the production performance of swamp buffaloes. Nevertheless, control measures are needed to prevent the future spread of the disease in herds.

\section{Authors' Contributions}

NN, FS, EBR, DAA, and SM designed the study. NN collected and examined the fecal samples. FS helped to perform statistical analysis, data interpretation, and the drafting process. EBR and SM cosupervised the laboratory examination. DAA contributed to the analysis of the impact of trematode infection against production performance parameters as well as revising and editing the manuscript. All authors read and approved the final manuscript.

\section{Acknowledgments}

The authors would like to thank the Ministry of Research, Technology, and Higher Education, the Republic of Indonesia (Grant number: 136/SP2H/LT/ DPRM/IV/2017 and 129/SP2H/PTNBH/DPRM/2018) for providing the research grant through the Master Leading to Doctoral Degree Education for Outstanding Graduate (PMDSU) Program. This study is a part of Ph.D. research of Nanis Nurhidayah at Parasitology and Medical Entomology Study Program, Graduate School of IPB University, Bogor, Indonesia.

\section{Competing Interests}

The authors declare that they have no competing interests.

\section{Publisher's Note}

Veterinary World remains neutral with regard to jurisdictional claims in published map and institutional affiliation.

\section{References}

1. El Debaky, A., Kutchy, N.A., Ul-Husna, A., Indriastuti, R., Akhter, S., Purwantara, B. and Memili, E. (2019) Review: Potential of water buffalo in world agriculture: Challenges and opportunities. Appl. Anim. Sci., 35(2): 255-268.

2. Talib, C., Herawati, T. and Hastono. (2014)Strategies for increasing buffalo productivity through improvement in feed and genetic. Wartazoa, 24(2): 83-96.

3. BPS-Statistic Indonesia. (2019) Population of Indonesian Buffaloes. BPS, Jakarta, Indonesia.

4. Winaya, A., Sukri, A., Gofur, A. and Amin, M. (2019) The genetic divergence and phylogenetic relationship of Indonesia swamp buffalo (Bubalus bubalis) based on partial sequences of cytochrome B gene of mitochondrial DNA. Int. J. Eng. Technol., 8 (1.9): 96-100.

5. Gueguen, E., Leperre, P., Petit, H., Merlin, A. and Chartier, C. (2016) A coproscopical study of helminthosis in domestic ruminants (cattle, buffalo, goat) in Khammouane province (Lao PDR). Rev. Méd. Vét., 167(11-12): 310-315.

6. Khadijah, S., Ariff, Z., Nurlaili, M.R., Sakiinah, A., Izzudin, A.H., Mursyidah, A.K., Rita, N. and Aida, H.N. 
(2017) Fasciola and Paramphistomum infection in large Ruminants. Int. J. Agron. Agric. Res., 10(6): 19-26.

7. O'Shaughnessy, J., Garcia-Campos, A., McAloon, C.G., Fagan, S., de Waal, T., McElroy, M., Casey, M., Good, B., Mulcahy, G., Fagan, J., Murphy, D. and Zintl, A. (2017) Epidemiological investigation of a severe rumen fluke outbreak on an Irish dairy farm. Parasitology, 145(7): 948-952.

8. Howell, A., Baylis, M., Smith, R., Pinchbeck, G. and Williams, D. (2015) Epidemiology and impact of Fasciola hepatica exposure in high-yielding dairy herds. Prev. Vet. Med., 121(1-2): 41-48.

9. Aragaw, K. and Tilahun, H. (2019) Coprological study of trematode infections and associated host risk factors in cattle during the dry season in and around Bahir Dar, Northwest Ethiopia. Vet. Anim. Sci., 7(1): 1-7.

10. Lee, J.K., Rosser, T.G. and Cooley, J. (2016) Pulmonary embolization of immature Fascioloides magna causing fatal hemothorax confirmed by molecular technique in a heifer in the United States. J. Vet. Diagn. Invest., 28(5): 584-588.

11. Suhardono, S., Estuningsih, S.E., Widjajanti, S., Natalia, L. and Kalianda, J.S. (1999) Fasciolosis on buffaloes which reared in swamp land in South Kalimantan (Indonesia). Proceeding of Veterinary and Livestock Management Seminar. Indonesian Research Institute for Animal Production (IRIAP), Bogor. p571-578.

12. Hambal, M., Sayuti,A. and Dermawan,A. (2013) Susceptibility of bovine and Bubalis spp on Fasciola gigantica in Lhoong sub-district Aceh Besar. J. Med. Vet., 7(1): 49-53.

13. Budiono, N.G., Satrija, F., Ridwan, Y., Nur, D. and Hasmawati, H. (2018) Trematodoses in cattle and buffalo around schistosomiasis endemic areas in Central Sulawesi Province of Indonesia). Indonesian J. Agric. Sci.,., 23(2): $112-126$

14. Oldeman, L.R. (1975) An Agro-climatic Map of Java. LIPI, Bogor. p14-22.

15. Nurhidayah, N., Satrija, F. and Retnani, E.B. 2019. Gastrointestinal parasitic infection of swamp buffalo in Banten province, Indonesia: Prevalence, risk factor, and its impact on production performance. Trop. Anim. Sci. J., 42(1): 6-12.

16. Gunawan, A. and Putera, B.W. (2016) Application of linier body measurements for fenotipic selection of dam PO cattle in Bojonegoro district. J. Anim. Prod. Process. Technol., 4(3): 375-378

17. Willingham, A.L., Johansen, M.J. and Barnes, E.H. (1998) A new technic for counting Schistosoma japonicum eggs in pig faces. Southeast Asian J. Trop. Med. Public Health, 29(1): 128-130.

18. Pandya, S.S., Hasnani, J.J., Patel, P.V., Chauhan, V.D., Hirani, N.D., Shukla, R. and Dhamsaniya, H.B. (2015) Study on prevalence of Fasciolosis in buffaloes at Anand and Ahmedabad districts, Gujarat, India. Vet. World, 8(7): 870-874.

19. Raza, M.A., Ayaz, M.M., Nazir, M.M., Akhtar, M.S., Aziz, M., Murtaza, S. and Khosa, M.A. (2016) Crosssectional survey of helminthiasis in buffaloes at Tehsil Jatoi and Tehsil Muzaffar Gahr, Southern Punjab, Pakistan. Buffalo Bull., 35(1): 39-48.

20. Lumain, J.P.L. and Balala, L. (2018) Suitability of danish bilharziasis laboratory technique (DBL) as detection test for trematode infection in buffaloes. CLSU Int. J. Sci. Technol., 3(2): 1-8.

21. Budiono, N.G., Satrija, F., Ridwan, Y., Handharyani, E. and Murtini, S. (2019) The contribution of domestic animals to the transmission of schistosomiasis japonica in the Lindu sub-district of the central Sulawesi province, Indonesia. Vet. World, 12(10): 1591-1598.

22. Satyawardana, W., Ridwan, Y. and Satrija, F. (2018) Trematodosis in beef cattle in 'Sentra Peternakan Rakyat' Sub district of Kasiman, District of Bojonegoro. Acta Vet.
Indones., 6(2): 1-7.

23. Mukhlis, A. (1985) Identity and life-cycle of liver fluke (Fasciola spp.) in Indonesia. [Doctorate Tesis]. IPB University, Bogor, ID.

24. Hayashi, K., Ichikawa-Seki, M., Allamanda, P., Wibowo, P.E., Mohanta, U.K., Sodirun S., Guswanto, A. and Nishikawa, Y. (2016) Molecular characterization and phylogenetic analysis of Fasciola gigantica from Western Java, Indonesia. Parasitol. Int., 65(5): 424-427.

25. Taylor, M.A., Coop, R.L. and Wall, R.L. (2016) Veterinary Parasitology. $4^{\text {th }}$ ed. Blackwell Publishing, Oxford. p259-803.

26. Hansen, J. and Perry, B. (1994) The Epidemiology, Diagnosis and Control of Helminth Parasites of Ruminants: A Handbook. ILRAD, Nairobi. p1-71.

27. Dreyfuss, G., Abrous, M., Vignoles, P. and Rondelaud, D. (2004) Fasciola hepatica and Paramphistomum daubneyi: vertical distribution of metacercariae on plants under natural conditions. Parasitol. Res., 94(1): 70-73.

28. Malrait, K., Verschave, S., Skuce, P., Van Loo, H., Vercruysse, J. and Charlier, J. (2015) Novel insights into the pathogenic importance, diagnosis and treatment of the rumen fluke (Calicophoron daubneyi) in cattle. Vet. Parasitol., 207(1-2): 34-139.

29. Kaplan, R.M. (2001) Fasciola hepatica: A review of the economic impact in cattle and considerations for control. Vet. Ther., 2(1): 40-50.

30. Pfukenyi, D.M., Mukaratirwa, S., Willingham, A.L. and Monrad, J. (2006) Epidemiological studies of Fasciola gigantica infections in cattle in the highveld and lowveld communal grazing areas of Zimbabwe. Onderstepoort $J$. Vet. Res., 73(1): 37-51.

31. Ridwan, Y., Kusumamiharja, S., Dorny, P. and Vercruysse, J. (1996) The epidemiology of gastrointestinal nematodes of sheep in West Java Indonesia. Hemera Zoa, 78(8): 8-18.

32. Suhardono, S. Roberts, J.A. and Copeman, D.B. (2006) Distribution of metacercariae of Fasciola gigantica on rice straw. Trop. Anim. Health Prod., 38(2): 117-119.

33. Gul-E-Nayab G., Muhammad, I., Niaz, S., Ali, Z. and Kattak, S.A. (2017) Prevalence of gastrointestinal parasite, Paramphistomum in domestic animals (cows and buffaloes) of district Swat and Charsadda, KP, Pakistan. J. Entomol. Zool. Stud., 5(3): 907-911.

34. Suhardono, D. and Copeman, D.B. (2008) Epidemiology of Fasciola gigantica in cattle and buffalo. In: Gray, G.D., Copland, R.S. and Copeman, D.B., editors. Overcoming Liver Fluke as a Constraint to Ruminant Production in South-East Asia. Australian Centre for International Agricultural Research, Canberra. p37-54.

35. El-Tahawy, A.S., Kwan, N. and Sugiura, K. (2018) Fasciola hepatica infection in water buffalo Bubalus bubalis in three provinces of the Nile Delta, Egypt: A cross-sectional study. J. Vet. Med. Sci., 80(1): 28-35.

36. Wiedosari, E., Hayakawa, H. and Copeman B. (2006) Host differences in response to trickle infection with Fasciola gigantica in buffalo, Ongole and Bali calves. Trop. Anim. Health Prod., 38(1): 43-53.

37. Sheng, Z.A., Li, J., Wang, D.Y., Kang, Y.Q., Wei, Z.Y., Zhang, F.K., Zhu, X.Q., Luo, H.L. and Huang, W.Y., (2019) Th2-related cytokines are associated with Fasciola gigantica infection and evasion in the natural host, swamp buffalo. Vet. Parasitol., 268(2019): 73-80.

38. Tarczynski, S. and Podkówka, W. (1964) Effect of ensilage of green roughage and drying of hay on viability and infectivity of Fasciola hepatica metacercariae. I. Metacercariae in the silage. Acta Parasitol. Pol., 12(20): 201-208.

39. Wahyuni, S., Sunarso, S., Prasetiyono, B.W.H. and Satrija, F. (2019) Exploration of anthelmintic activity of Cassia spp. Extracts on gastrointestinal nematodes of sheep. J. Adv. Vet. Anim. Res., 6(2): 236-240. 